\title{
La Evolución Artística de José G. Antuña
}

F $N$ la personalidad de José G. Antuña pueden señalarse, con relieve y fuerzas propias, el periodista, el orador, el escritor, el político y el internacionalista. Pero en él la presencia del poeta se destaca e impone, dominante. La poesía llega aquí, como acontece casi siempre, como el coronamiento de una intensa vida espiritual, después de profundas y amplias luchas intelectuales.

En la juventud ya aparecía el poeta, entregando como un fruto de alegría el canto ardiente. Luego otras ocupaciones más intensas y otras preocupaciones vitales más poderosas apartaròn a José $\mathrm{G}$. Antuña del culto agotador de la estrella. Dejó de cantar para empeñarse noblemente en más arduas disciplinas intelectuales. Pero el poeta seguía vivo en él, sin que de ello se percatara: estaba en ese impulso permanente de ascensiones, de investigaciones, de arrebatos y de luchas idealistas, que explican y justifican su vida.

El celeste dón poético, cuando es verdadero, se puede ocultar por algún tiempo, pero después de largos silencios, surge inesperada y vengativamente, imponiéndose arrollador y único. Así ha acontecido con el autor inspirado de El inquieto horizonte.

En la rica y copiosa bibliografía de este escritor, será necesario destacar un libro de versos altamente significativos, escrito en París en el año 1925, bajo el título de Los viejos ritmos. Ya el artista entonces, con cierto inquietante desgano, se preguntaba:

¿Todavía versos?

¿Y el pájato gris de tu sentimiento podrá recoger los ritmos dispersos en el viento? 


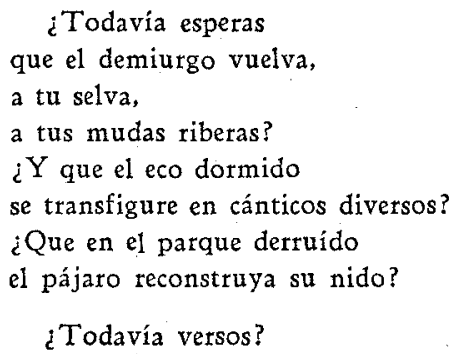

No era ésta una postura de poeta romántico, sino que traducía una verdadera convicción interior, ya que José G. Antuña, desde entonces, como poeta, guardó un profundo silencio. Ahora, la canción le brota nuevamente, con más brío, con más pujanza, con más claridad que nunca. Y la canción llega en la hora de su mejor y más exacto arribo.

Muchos, ingenuamente, creen que el verso es faena de los años mozos. Grave error. El verso mejor, por lo general, es el feliz y radiante coronamiento de una filosofía, de toda una cultura. Y llega más claro y convincente también, cuando los años han pasado por nosotros, con su carga de dolor, de desengaño y de pruebas amargas. Job ha visto muchas cosas; ha vivido mucho y sobre todo ha sufrido mucho, cuando desde su lecho de estiércol y paja, alza, como un oleaje de ceniza y fuego, su oración esperanzada.

Es el símbolo más acabado del poeta.

En plena madurez intelectual, José G. Antuña vuelve, pues, lógicamente al canto. Un canto que será como la venganza del poeta -desde el año 1925, silenciado o negado-, de quien se dedicaba afanosamente a otras actividades intelectuales.

En el año 1938, como delegado del Instituto de Cooperación Intelectual, que en Bruselas estudiaba el "Estatuto universal de defensa del escritor", hizo un nuevo viaje a Europa.

El mar se apoderó de su espíritu y despertó para nuevas creaciones de belleza al dormido artista. E1 mar jamás defrauda al soñador que se le enfrenta, ni niega la sugestión de divina hermosura a quien sepa mirar su rostro.

¿Cuán exacto aquel verso de Baudelaire: "Homme libre toujours tu cheriras la mer"! 
De aquel viaje le nació, muy contra el corazón, un nuevo libro de versos. Se llama Los cantos de Atlantida y el mar.

Son cuarenta poemas de una gran variedad formal, temática y emotiva. En algunos de ellos José G. Antuña no ha podido arrancar de sí mismo el ancho ademán oratorio que le caracteriza. Pero tal elocuencia se justifica, por ese sentido cósmico que le sostiene e impulsa, frente al enorme espectáculo del Océano en cambios y en luchas. Además abundan las referencias a nombres, personajes y gestas de la antiguiedad clásica. Es que, pegado al poeta, José G. Antuña lleva el historiador y el pensador ansioso de buscar en la noche de pasadas edades la raíz de muchos de nuestros actuales sentimientos y pensamientos.

Otros poemas son descriptivos, pero no tanto, que lleguen a despojarse totalmente de subjetividad. José G. Antuña, con giros felices, con imágenes de singular gracia, pinta el cuadro del mar cambiante a través de la marcha de las horas, pero siempre está su misma alma, reflejándose o viviendo en el paisaje que se complace en recrear.

Cantos de Atlántida y el mar es un libro escrito por un artista de verdad, que sabe contener o regular la emoción y en quien la aguda sensibilidad se equilibra por cultivada inteligencia. Por él comprenderá José G. Antuña que el "demiurgo volvió a la selva del canto" y que "el pájaro gris del sentimiento ha recogido los ritmos dispersos": ritmos de muchas horas, ritmos de muchos paisajes, y sobre todo, los ritmos del alma siempre empinada hacia la altura. Oigamos algunos de ellos:

Numquid ingresus es profundis maris et novissimus abyassi deambulasti?

JoB. C. XXXVIII.

¡Pater Oceanus!

Quisiera algún día cantar tu infinito en el infinito de tu orquestación.

$Y$ cantarte invocando el acento que viene del mísero lecho de paja de Job. 
¿Pater Oceanus! Tu monstruosa historia yo quisiera cantarla algún día en su plena apoteosis triunfal: Mundo, Orden, Belleza.

Fundir la estrofa en el fuego y el agua; en tu enorme presencia de Leviatán.

Y junto al Cosmos: Belleza, Orden, Mundo, la incandescencia de la Nebulosa $y$ el Caos primordial.

¿Pater Oceanus! ¿Yo nunca he de cantarte la amarga sinfonía de tu historia? ¿La de tus Islas y tus Continentes? ¿La elegía de los pueblos del mar? $\mathrm{Tu}$ imperio plutoniano y tus diluvios; tus duelos, tus venganzas y tus fugas, tus metamórfosis; tu innumerable progenitura.

De nuevo a tus convulsos dominios me internan las legiones de tus ondas.

Hemos traspuesto las columnas de Hércules bogando sobre el líquido sarcófago de "los pueblos del mar".

Aquí fué Atlántida. Y aquí el Océano aniquiló en su gesta milenaria las tierras, las ciudades y las razas.

Quiero cantar su saña y su fecundidad, mientras que la leyenda hincha las velas de esta nave lunar. .

$$
* * *
$$

Hay que cegar los puertos y romper el timón y la hélice de los navios.

JUANA DE AMÉRICA

$Y$ artojarse, sin náutica, entre los vientos y los astros, 
en la vorágine de este constante infinito,

con la proa del corazón.

Pero no al impulso monstruoso

de los émbolos y los motores y las radios.

Y lejos de la piratería de los nuevos corsarios,

borrar los puertos de los mapas del alma,

a la conquista del refugio etrante,

en los ebrios periplos del sueño.

$* * *$

MAR DE GALILEA

.. nic quia venti et mare abédiunt si...

MATTH.-8, 23-27.

Fides tua te salvam fecit: vade in pace.

LUC. $-7,36-50$.

Hace veinte siglos que guatda las buellas

de los pies divinos...

Cristo caminando sobre su corriente

remontó el prodigio.

Vió pasar la barca de los pescadores

el oleaje fiero:

las redes vacías y las redes llenas:

la duda de Pedro.

Hace veinte siglos que pasó el milagro

por su superficie;

la sed del desierto de la penitencia;

la voz del Bautista.

Caja de los cánticos y de las parábolas:

laúd de los astros.

Ya pasa el Arcángel, ya pasa la nívea

paloma del salmo.

Las voces celestes y los asfodelos

aroman sus noches;

cantan los olivos y los limoneros

en sus horizontes.

Mar de Galilea que cruzó el Mesías

con sus pies divinos...

(y el Padre y el Hijo y el Espíritu Santo). 
Sus aguas son menos profundas $\mathrm{y}$ ardientes que el llanto infinito

de la mujer mala que a los pies del Justo se puso a llorar.

Y enjugó su llanto con su cabellera.

$\mathrm{Y}$ alejóse en paz...

Mar de las plegarias, que cruzó el milagro de los pies divinos...

Todavía están blancos y húmedos de espuma. ¡Todavía están fríos!

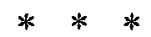

...Et nous voila marchant sut le chemin amet.

VERLAINE

$Y$ he aquí que avanzamos por las rutas amargas...

Las ondas son de cera, y el sol de vidrio guarda el ascua de luz del mediodía.

Y el pueblo de los pájaros en los bosques del cielo busca y no encuentra la surgente umbría.

$Y$ he aquí que avanzamos por las rutas amargas. . . El crepúsculo cobra las formas imprecisas del alma, del matiz y del perfume.

$\mathrm{Y}$ he aquí que avanzamos en la noche marina... Noche cerrada. Pescadora de estrellas en la red de las nubes.

\author{
ERNESTO Pinto, \\ Montevideo.
}

